\title{
USING FACEBOOK AS A SPORT MARKETING TOOL: A CONTENT ANALYSIS ON TURKISH SOCCER CLUBS
}

\author{
Metin ARGAN*, margan@anadolu.edu.tr \\ Mehpare Tokay ARGAN' ${ }^{\dagger}$, mehpare.argan@bilecik.edu.tr \\ Hüseyin KÖSEł, huseyink@anadolu.edu.tr \\ Burak GÖKALP\$, bgokalp@anadolu.edu.tr
}

In sports industry by using social media sports clubs or organizations generate promotional information in the form of blogs, photos and videos prior to their events, organizations or about their licensed products. In this study the purpose is to put forth a descriptive analysis of using Facebook in soccer clubs as a marketing tool and to shed light on quantitative and qualitative studies that might be undertaken in the future. The researchers content analyzed Facebook pages of five popular soccer clubs in Turkish Super League. In the study the researchers analyzed Facebook pages in terms of general features and marketing activities. Then four themes revealed including; Facebook profile information, promotional applications, licensed product applications and news (about game tickets, events and games, sport clubs).

Key words: Marketing, sports marketing, social media, Facebook.

JEL Codes: M31

\section{Facebook'u spor pazarlaması aracı olarak kullanma: Türk futbol kulüplerinde içerik analizi}

Spor endüstrisinde spor klüpleri ve organizasyonları etkinlik, organizasyon ya da lisanslı ürünlerinden önce blog, resim, video biçimlerinde tutundurma bilgileri oluşturmaktadırlar. Bu çalışmanın amacı Facebook'u futbol klüpleri için pazarlama aracı olarak kullanarak tanımlayıcı bir analiz oluşturmak ve gelecekte

\footnotetext{
* Anadolu Üniversitesi Öğretim Üyesi

+ Bilecik Şeyh Edebali Üniversitesi Öğretim Üyesi

‡ Anadolu Üniversitesi Araştırma Görevlisi

§ Anadolu Üniversitesi Spor Yön. Böl.
} 
Argan M., Argan M.T., Köse H. E Gökalp B.

yapılacak olan nicel ve nitel çalışmalara 1şık turmaktır. Türk Süper Lig'inden 5 takıma içerik analizi uygulanmıştır. Bu çalışmada araştırmacılar Facebook'un genel özelliklerini ve pazarlama aktivitelerini analiz etmişlerdir.

\section{INTRODUCTION AND BACKGROUND}

The popularity and growth of online social networks has created a new world of collaboration and communication. More than a billion individuals around the world are connected and networked together to create, collaborate, and contribute their knowledge and wisdom (Cheung et al., 2011). In recent decades, the "science of networks" has developed into a thriving field of social scientific inquiry (Watts, 2007). The growth of social network analysis as an academic field has coincided with an explosion in popular interest of social networks. This is due in part to the popularization of social network sites that allow individuals, (1) construct public or semipublic profile within a bounded system, (2) articulate a list of other users with whom they share a connection, (3) view and traverse their list of connections and those made by others within the system (Boyd \& Allison, 2007).

With the emergence of the phenomenon known as social media the tools and strategies for communicating with customers have changed significantly (Mangold \& Faulds, 2009). Social media (Facebook, twitter etc.) has exploded a category of online discourse where people create content, share and bookmark it and network at a prodigious rate. Because of its speed, reach and ease of use, social media is fast changing the public discourse in society and setting trends and at the top of the agendas for many business executives and in topics that range from the environment and technology to sports and entertainment industry today. This form of media also referred to as consumer-generated media, "describes a variety of new sources of online information that are created, initiated, circulated and used by consumers intent on educating each other about products, brands, services, personalities, and issues" (Blackshaw \& Nazzaro, 2004). Social media encompasses a wide range of online, word-of-mouth forums including blogs, company-sponsored discussion boards and chat rooms. Also it includes consumer-to-consumer e-mail, consumer product or service ratings websites and forums, Internet discussion boards and social networking websites (Mangold \& Faulds, 2009). Social networks serve a number of functions in offline life like providing social and emotional support (Donath \& Boyd, 2004). Lampe et al. (2006) draw a distinction between the use of social network (Facebook) for social searching and social browsing.

By using social networking sites, users can create personal information profiles, invite friends and colleagues than access their profiles, send messages and emails each other. These personal profiles can include any type of information,

IUYD'2013 / 4(1) 
including photos, audios, videos and blogs. According to Wikipedia, the largest social networking site is Facebook (Kaplan \& Haenlein, 2010). It is one of the most popular social media forms and is the first dataset of its kind to be made publicly available. Facebook is designed to appeal to scholars of diverse interests including those interested in studying relationship between virtual and real life social spaces. It allows users to create personal profiles including demographic features, information about their background and also photo albums and videos (Lewis et al., 2008).

In 21th century consumers are turning away from traditional advertising sources like television, radio or newspapers (Mangold \& Faulds, 2009). They are also consistently demand more control over their media consumption. They require on-demand and immediate access to information at their own convenience (Rashtchy et al., 2007). So, the 21st century is witnessing an explosion of Internetbased messages transmitted through social media. They have become a major factor in influencing various aspects of consumer behavior including awareness, information acquisition, opinions, attitudes, purchase behavior, and postpurchase communication and evaluation (Mangold \& Faulds, 2009). Several companies use social networking sites to support the creation of brand communities (Muniz \& O'Guinn, 2001) or for marketing research in the context of netnography (Kozinets, 2002). The existence of social media offers advanced relationships and targets opportunities for marketers in consumer markets (Mangold \& Faulds, 2009). Social media has made it possible for businesses to communicate instantaneously and simultaneously with consumers (B2C) and consumers to communicate with other consumers $(\mathrm{C} 2 \mathrm{C})$ regarding products, brands and services continuously.

For sport organizations the Internet is a unique method to communicate with their fans and potential consumers. It is a tool that sport organizations have focused on communicating, selling, and marketing to their fans (Blazska, 2011). They utilize their official website but it provides limitless information on the team (Filo and Funk, 2005). By the growing influence of social media (Safko, 2010) sport fans began to use these new innovations to stay connected to their favorite sport teams. As a result, sport organizations able to reach out to their fan base to provide information about the organization and thus market their service and product better (Lukach, 2012). Also, sport organizations use social media to share news, information and content with potential consumers. For sport clubs, using Facebook characterizes a way of communication with their fans. For example, Facebook enables sport clubs to connect the fan personally and for fans connecting with a team of Facebook has a strong relationship to team identification (Broughton, 2011). It also provides sport organizations a channel of 
Argan M., Argan M.T., Köse H. E Gökalp B.

communication to post news about their programs and create better brand awareness (Wallace et al., 2011).

Today sport organizations are realizing the benefits of social media and are seeking ways to most effectively use them as a part of their overall marketing and communication strategies (Coyle, 2010). According to Wallace et al. (2011) social media provides a strategic means for sport organizations to build and maintain a strong brand presence when building up relationships with Facebook users. Facebook helps sport organizations to communicate unfiltered messages directly to their fans. Nonetheless, sport organizations can capture the attention of a large population with the aid of Facebook by sending out game and event information or creating events through Facebook that provide another way for fans to interact with the organization (Lukach, 2012). According to Coyle (2010) sport clubs must actively use social media to enhance brand management, encourage social interactions among fans, promote ticket sales and present a better online experience.

Soccer, commonly referred to as the world's favorite sport, dominates the international sports arena and is passionately followed by avid fans. And today like all businesses, soccer uses social media one of its essential part of marketing tool (Bunting, 2012). For soccer teams, social media plays an important role to interact, connect and collaborate with their fans. It can be stated that teams can use social media through their Facebook accounts for their marketing public relations purposes such as promotion, sales, marketing and advertising support (Peltekoglu \& Hurmeric, 2012). Briefly, the ability to use soccer clubs' Facebook page effectively managers of clubs to encourage and facilitate the fans referring to the club's page and in addition creates loyalty in fans and increase the club benefit from selling licensed products, game tickets etc. (Ramizadeh et al., 2012).

Unfortunately, the popular business press and academic literature offers marketing managers little guidance for incorporating social media into their marketing communication strategies (Mangold \& Faulds, 2009). While much is known about communication strategies of many businesses using social media, little is known about sport clubs communication strategies with their fans using social media. Based on this notion and related literature the study aims to determine using social media as a marketing communication tool of sport clubs of Turkish Super League.

\section{METHOD}

The main purpose of this study is to provide a comprehension of how social media used as a strategic marketing tool of sport clubs. In order to collect the 
required data qualitative research method was used. Content analysis is appropriate approach in terms of qualitative research. Content analysis in qualitative research is a technique for gathering data. Content analysis has been successfully used in a variety of marketing research settings including research on websites (Bodkin \& Perry, 2004). The basic aim of content analysis is to identify notions and relations that would define the collected data (Yildirım \& Simsek, 2006; Argan et al., 2006). It involves codifying qualitative and quantitative information into pre-defined categories in order to derive patterns in the presentation and reporting of information (Guthrie \& Abeysekera, 2006). For this reason, the content analysis starts with the coding of data. In this study, the coding scheme includes twelve measurement items. They were specified from the literature review and Facebook website features including photos, video sharing, events, present and other applications. The items of measurement used in the content analysis included two parts. The five items in the first part were; The photos and videos about the soccer team, news about games, fan events, promotion activities (presents, drawings, campaigns, information about licensed products) and news about players. The seven items in the second part were; information about Facebook page, history, likes, update frequency, contact information, language option and links. The researchers content analyzed Facebook pages of five popular soccer clubs (Besiktas, Eskisehirspor, Fenerbahce, Galatasaray, Trabzonspor) in Turkish Super League on these specified 12 items from 1 March to 15 May 2012. Content analysis forms were then analyzed for frequencies and percentages of related features using SPSS.

As Gesternfeld, Grant \& Chiang (2011) point out, a purposive sampling method is appropriate for content analysis of websites. In this study, method of purposive sampling method was employed. The selected sample was the Facebook pages of five clubs in Turkish Super League. All of these clubs have a significant number of fans, high brand value and economic status. For content analysis to be effective, certain technical requirements should be met (Guthrie et al., 2004). First, the categories of classification must be clearly and operationally defined, that is, the units of analysis. Second, data capture must be systematic. It must be clear that an item either belongs or does not belong to a particular category. Third, content analysis must demonstrate some characteristics for reliability and validity (Guthrie \& Abeysekera, 2006). The data gathered to the research is conducted as systematic base.

As indicted by Li \& Wang (2011), three trained evaluators (researchers in this paper) assessed the websites using the evaluating instrument adapted from literature. Before evaluating teams' Facebook pages, practice sessions were carried out to ensure that these evaluators were familiar with the evaluation criteria used in this study and capable of assessing pages independently and 
Argan M., Argan M.T., Köse H. E Gökalp B.

impartially. The data gathering process indicate reliability and validity dimensions. According to Milne and Adler (1999), reliability in content analysis involves two separate issues. First, it is necessary to attest that the coded data set produced from the analysis is reliable. This is usually achieved by the use of multiple coders and by reporting that the discrepancies between coders are minimal. Another factor to consider is the reliability associated with the coding instrument. Establishing the reliability of particular coding tools reduces the need for multiple coders (Guthrie \& Abeysekera, 2006). Three trained researchers can be evaluated as reliability, in terms of multiple coders. The percentage of agreement method (Kassarjian, 1977) was employed to determine the coefficient of inter-coder reliability for 33 category items used in the framework and it is widely acknowledged that inter-coder reliability is a critical component of content analysis (Lombard et al., 2002). In the coding stage of this research, two coder groups were formed and both encoders then independently coded data.

\section{FINDINGS AND RESULTS}

In this study, five popular Turkish Super League soccer clubs' (Besiktas, Eskisehirspor, Fenerbahce, Galatasaray, Trabzonspor) Facebook pages were content analyzed in terms of general features, likes, shared events and marketing applications. All of the teams' Facebook pages respectively visited and content analyzed via evaluation criteria adapted from literature. Then four themes revealed including; Facebook profile information, promotional applications, licensed products applications and news (about game tickets, events and games, sport clubs).

\section{Facebook Profile Information}

In their Facebook pages, sport clubs share their historical information, communication addresses, telephone numbers, e-mail etc. When analyzing these items, the most detailed information was in Besiktas and Fenerbahce's pages. They also had e-mail and contact number in their Facebook pages. When assessing historical information about the teams on the pages, Fenerbahce comes forward. None of the teams had information about their history but Besiktas just had foundation date.

In terms of number of the likes of Facebook pages, Galatasaray was the first with 6.782.021 likes, Fenerbahce had 5.615.122 likes and the third was Besiktas with 3.536.342 likes. Trabzonspor had 415.192 and Eskisehirspor had 191.549 likes. And, none of the teams used language option in their Facebook pages. While Fenerbahce had a chat room and TV channel option on Facebook page, Galatasaray just had TV Channel option, the others didn't have. 
Promotional Applications

By assessing the Facebook pages of the teams, another revealing theme was the shares about promotional activities including campaigns, gifts and discounts. In Facebook pages of Fenerbahce and Galatasaray there were too many promotional activities about discounts and gifts. For example, there were competitions for match tickets and licensed products. In Besiktas and Trabzonspor pages there were campaigns about magazine subscription.

\section{Licensed Product Applications}

In terms of licensed product applications theme, when assessing the Facebook pages of sport clubs, there was information about licensed products, shops and prices on the pages. Fenerbahce and Galatasaray had the most effective pages because of using Facebook as a shop. There were links to their online stores, information about discounted products etc. On the other hand Besiktas, Trabzonspor and Eskisehirspor had any applications about licensed products in their Facebook pages.

News

Another theme revealed when assessing Facebook pages of sport clubs was News. News can be assessed in three dimensions named "news about games tickets, news about events and games, and sport clubs.

- News about game tickets

In terms of ticket sale and dealing information via Facebook, Fenerbahce comes forward. Besiktas, Galatasaray and Trabzonspor use Facebook pages less than Fenerbahce for ticket information. There were no applications about news about game tickets in the pages of Eskisehirspor.

\section{- News about game events and games}

By using Facebook sport clubs can announce their events and games easily and fast. By Facebook clubs can present news about pre game, game itself and post-game in real time. So the users of Facebook can follow the news and comment on them at the same time. When considering these data and assessing the pages of the five soccer clubs they are all used effectively and updated frequently.

\section{- News about sport clubs}

News about players and transfers, interviews with managers, coaches or players etc. can be assessed in the theme "News about sport clubs". Fans can follow all the news and can comment on. When assessing these items on the pages of the soccer clubs, all of them in the research use Facebook to present news about the team, players, events etc. 
Argan M., Argan M.T., Köse H. E Gökalp B.

\section{CONCLUSION}

Generally, customer behavior changes over time and for sport fans it is the same. Today, organizations use different ways to understand their customers and service them as the way they wish. Using social media is one of the best ways to understand and communicate for the firms with their customers. Because as Mangold \& Faulds (2009) stated social media is a major factor in influencing various aspects of consumers' behavior. But, while much is known about communication strategies of many businesses using social media, little is known about sport clubs communication strategies with their fans using social media.

So, the aim of the study is to show what should be taken into consideration for sport clubs to communicate with fans using Facebook, the largest social networking site. By including Facebook in to their marketing strategies, sport clubs have the ability to promote their events and licensed products directly to consumers. Also Facebook makes it possible for one fan to communicate with thousands of fans about their teams, organizations etc. Therefore the marketing managers of the clubs have to learn to shape their fans discussions that are consistent with the clubs' mission and goals. This is going to be possible by using social media effectively. In the study the researchers aimed to determine using Facebook as a marketing communication tool of sport clubs of Turkish Super League. Then four themes revealed and named Facebook profile information, promotional applications, licensed product applications and news (about game tickets, events and games, sport clubs). The most important contribution of the study is to show that Facebook can be used as a marketing tool. Sports clubs' can communicate with their fans, promote their events, sell their licensed products and much more by using Facebook.

As with all research, this study is not free of some limitations, and it suggests avenues for future research consideration. The current study focused specifically on a limited number of teams in Turkish Super League. Data was collected on only five soccer clubs' Facebook pages in Turkey. Researchers are not able to perform content analysis of all 18 teams in Turkish Super League or multi leagues to generalize the results to whole of the marketplace because of time and cost limitations. The results found in the research may be markedly different given another teams, another league or sport branches. 


\section{ACKNOWLEDGEMENTS}

The current study was submitted as an oral presentation at 2012 Intellectbase Multi-Disciplinary Academic Conference, International Conference in Las Vegas, USA, December 13-16, 2012.

\section{REFERENCES}

Argan, M., Er, I., Kilicer, T. and Ozata, Z. (2006). The Evaluation of Sponsorship Effectiveness: A Content Analysis Study on Televised Formula One Istanbul Grand Prix, 6th International Conference on Sports: Economic, Management and Marketing Aspects, June 29-30. An Amalgam of Sport and Exercise Research Proc.Book, 213-228.

Blackshaw, P., and Nazzaro, M. (2004). Consumer-Generated Media (CGM) 101: Word-of-mouth in the age of the Webfortified consumer (http://www.nielsenbuzzmetrics.com/whitepapers).

Blaszka, M. (2011). An examination of sport consumers' twitter usage, Kinesiology Theses, Paper 1.

Broughton, D. (2010). Survey: Social media use builds fan avidity. Sport Business Journal. Retrieved from: http://www.sportsbusinessdaily.com/Journal/Issues/ 2010/07/20100726/This-Weeks-News/Survey-Social-Media-Use-Builds-FanAvidity.aspx

Boyd, D. M. and Ellison, N. B. (2008). Social network sites: Definition, History, and Scholarship. Journal of Computer-Mediated Communication, 13, 210-230.

Bunting, R. C. (2012). Social network: The case of Major League Soccer and Facebook likes, CMC Senior Theses, Paper 468. http://scholarship.claremont.edu/cmc_theses/468

Cheung, C.M.K., Chiu, P. and Lee, M.K.O. (2011). Online social networks: Why do students use Facebook? Computers in Human Behavior, 1337-1342.

Coyle, P. (2010). Teams active in social media build strategic advantage, Street \& Smith's Sports Business Journal, 12, 18.

Donath, J. and Boyd, D. (2004). Public displays of connection. BT Technology Journal, 22(4), 71-82.

Filo, K. and Funk, D. C. (2005). Congruence between attractive product features and virtual content delivery for İnternet marketing communications. Sport Marketing Quarterly, 14(2), 112-122. 
Argan M., Argan M.T., Köse H. E Gökalp B.

Guthrie, J. and I. Abeysekera (2006). Content analysis of social, environmental reporting: What is new? Journal of Human Resource Costing and Accounting 10(2), 114-126.

Kaplan, A. M. and Haenlein, M. (2010). Users of the world, unite! The challenges and opportunities of social media. Business Horizons, 53, 59-68.

Kassarjian, H.H. (1977). Content Analysis in Consumer Research, Journal of Consumer Research, 4: 8-18.

Kozinets, R. V. (2002). The field behind the screen: Using netnography for marketing research in online communities. Journal of Marketing Research, 39, 61-72.

Lampe, C., Ellison, N. and Steinfield, C., (2006). A Face(book) in the crowd: social searching vs. social browsing. Proceedings of CSCW-2006, ACM, New York, 167-170.

Lewis, K., Kaufman, J., Gonzalez, M., Wimmer, A. and Christakis, N. (2008). Tastes, ties, and time: A new social network dataset using Facebook.com. Social Networks, 30, 330-342.

Lombard, M., Snyder-Duch, J. and Bracken, C.C. (2002). Content analysis in mass communication: Assessment and reporting of intercoder reliability, Human Communication Research Association, (28), 587-604.

Lukach, J. (2012). The relationship between fan identification and student utilization of social media in a NCAA division I university, The Graduate Faculty of the University of Akron, theses.

Mangold, W.G. and Faulds, D.J. (2009). Social media: The new hybrid element of the promotion mix, Business Horizons, 52(4), 357-365.

Milne, M. and Adler, R. (1999). "Exploring the reliability of social and environmental disclosures content analysis", Accounting, Auditing and Accountability Journal, 12 (2): 237-256.

Muniz, A. M. and O'Guinn, T. C. (2001). Brand community. Journal of Consumer Research, 27(4), 412-432.

Peltekoglu Balta, F. and Hurmeric, P. (2012). Social media used as a marketing public relations tool in Turkish football teams, Selcuk Iletisim, 7(2), 5-13.

Rahimizadeh, M., Sajadi, S. N., Goodarzi, M. and Ghamati, H. (2012). A comparison of online marketing and interaction with fans through official website of football clubs in Iran, Asia and Europe, International Research Journal of Applied and Basic Sciences, 3(5), 1065-1071. 
Using Facebook as a Sport Marketing Tool

Rashtchy, F., Kessler, A. M., Bieber, P. J., Shindler, N. H., and Tzeng, J. C. (2007). The user revolution: The new advertising ecosystem and the rise of the Internet as a mass medium. Minneapolis, MN: Piper Jaffray Investment Research.

Safko, L. (2010). The Social Media Bible. Hoboken, New Jersey: John Wiley \& Sons Inc.

Wallace, L., Wilson, J. and Miloch, K. (2011). Sporting Facebook: A content analysis of NCAA organizational sport pages and Big 12 Conference Athletic Department pages. International Journal of Sport Communication, 4, 422-444.

Watts, D. J. (2007). A twenty-first century science, Nature, 445, 489.

Yıldırım, A. and Şimşek, H. (2006). Sosyal Bilimlerde Nitel Arastirma Yontemleri Qualitative Research Methods in Social Sciences], Seckin Yayincilik, Ankara. 